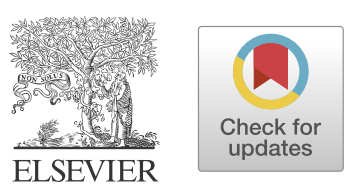

CJC Open 3 (2021) 1060-1074

\title{
Review
}

\section{Classical and Counter-Regulatory Renin-Angiotensin System: Potential Key Roles in COVID-19 Pathophysiology}

\author{
Moudhi Almutlaq, MSc, ${ }^{\mathrm{a}, \mathrm{b}}$ Abir Abdullah Alamro, PhD, ${ }^{\mathrm{b}}$ Fayhan Alroqi, MD, ${ }^{\mathrm{a}, \mathrm{c}, \mathrm{d}}$ and \\ Tlili Barhoumi, $\mathrm{PhD}^{\mathrm{a}, \mathrm{d}}$ \\ ${ }^{a}$ King Abdullah International Medical Research Centre, King Abdulaziz Medical City, Ministry of National Guard Health Affairs, Riyadh, Saudi Arabia \\ ${ }^{b}$ Department of Biochemistry, College of Science, King Saud University, Riyadh, Saudi Arabia \\ ${ }^{c}$ Department of Pediatrics, King Abdulaziz Medical City, King Abdullah Specialized Children's Hospital, Riyadh, Saudi Arabia \\ ${ }^{d}$ King Saud bin Abdulaziz University for Health Sciences, Riyadh, Saudi Arabia
}

\begin{abstract}
In the current COVID-19 pandemic, severe acute respiratory syndrome coronavirus 2 uses angiotensin-converting enzyme-2 (ACE-2) receptors for cell entry, leading to ACE-2 dysfunction and downregulation, which disturb the balance between the classical and counter-regulatory renin -angiotensin system (RAS) in favor of the classical RAS. RAS dysregulation is one of the major characteristics of several cardiovascular diseases; thus, adjustment of this system is the main therapeutic target. RAS inhibitors-particularly angiotensin-converting enzyme inhibitors (ACEIs) and angiotensin II type 1 receptor blockers (ARBs)-are commonly used for treatment of hypertension and cardiovascular disease. Patients with cardiovascular diseases are the group most commonly seen among those with COVID-19 comorbidity. At the beginning of this pandemic, a dilemma occurred regarding the use of ACEls and ARBs, potentially aggravating cardiovascular and pulmonary dysfunction in COVID-19 patients. Urgent clinical trials from different countries and hospitals reported that there is no association between RAS inhibitor treatment and COVID-19 infection or comorbidity complication. Nevertheless, the disturbance of the RAS that is associated with COVID-19
\end{abstract}

The severity of any infection is directly related to patients' predisposition and their current physical health, which affects the regular function of the immune system in fighting the virus. The innate and adaptive immune system plays a crucial role in the progression and development of various cardiovascular diseases. ${ }^{1-4}$ Impairment of the immune system in cardiovascular diseases renders patients more vulnerable to viral infection. ${ }^{5}$ The entry of severe acute respiratory syndrome coronavirus 2 (SARS-CoV-2) into human cells was first detected in respiratory cells through the interaction between the spike glycoprotein protein of SARS-CoV-2 and the angiotensin-converting enzyme-2 (ACE-2) receptor, causing COVID-19. ${ }^{6}$

Received for publication January 25, 2021. Accepted April 8, 2021.

Ethics Statement: This research has adhered to the relevant ethical guidelines.

Corresponding authors: Dr Tlili Barhoumi, King Abdullah International Medical Research Centre, Ministry of National Guard Health Affairs, Riyadh 11461, Saudi Arabia. Tel.: +1-966-543-159145.

E-mail: barhoumitl@ngha.med.sa

\section{RÉSUMÉ}

Dans l'actuelle pandémie de la COVID-19, le coronavirus du syndrome respiratoire aigu sévère 2 (SRAS-CoV-2) utilise les récepteurs de l'enzyme de conversion de l'angiotensine 2 (ECA-2) pour entrer dans les cellules, s'ensuit le dysfonctionnement et la régulation à la baisse de I'ECA-2, qui perturbent l'équilibre entre le système rénine-angiotensine (SRA) traditionnel et le SRA contre-régulateur en faveur du SRA traditionnel. La dysrégulation du SRA est l'une des caractéristiques principales des maladies cardiovasculaires. Par conséquent, l'ajustement de ce système est l'objectif thérapeutique principal. Les inhibiteurs du SRA, particulièrement les inhibiteurs de I'ECA (IECA) et les antagonistes des récepteurs de type 1 de l'angiotensine II (ARA), sont communément utilisés pour traiter l'hypertension et les maladies cardiovasculaires. Les patients atteints de maladies cardiovasculaires représentent le groupe le plus fréquemment observé parmi les patients atteints de comorbidités associées à la COVID-19. Au début de la pandémie, un dilemme à propos de l'utilisation des IECA et des ARA s'est posé, puisqu'ils aggravaient potentiellement la dysfonction cardiovasculaire et pulmonaire chez les patients atteints de la COVID-

Many COVID-19-infected patients either possessed one or more cardiovascular diseases or developed cardiac injuries later on in their infection period, with most of the severe cases being linked to cardiovascular diseases. ${ }^{5}$ Based on a recent report from China, only $4.68 \%$ of 278 COVID-19 deaths had no comorbidities, and the rest had at least one comorbidity. ${ }^{7}$

This expected effect is due to not only disturbance of the immune system, but also the virulence of SARS-CoV-2 that was shown by measuring the affinity of viral spike protein to the ACE-2 receptor of the host cell, which was up to 20 times stronger compared to SARS-CoV binding. ${ }^{8,9}$ ACE-2 is a crucial modulator of the renin-angiotensin system (RAS),

Moudhi Almutlaq, King Abdullah International Medical Research Centre, Ministry of National Guard Health Affairs, Riyadh 11461, Saudi Arabia. Tel.: +1-966-543-159145.

E-mail: Moudhi.a.almutlaq@gmail.com

See page1069 for disclosure information. 
infection and the potential treatment targeting this area have yet to be resolved. In this review, the link between the dysregulation of classical RAS and counter-regulatory RAS activities in COVID-19 patients with cardiovascular metabolic diseases is investigated. In addition, the latest findings based on ACEI and ARB administration and ACE-2 availability in relation to COVID-19, which may provide a better understanding of the RAS contribution to COVID-19 pathology, are discussed, as they are of the utmost importance amid the current pandemic.

playing a key role in the maintenance of cardiovascular functions in both normal and pathophysiological conditions. ${ }^{5}$

Per the World Health Organization's update of January 6,2021 , there have been 84,780,171 confirmed cases of COVID-19 and 1,853,525 deaths worldwide. ${ }^{10}$ ACE-2 depletion - associated with SARS-CoV-2 infection and the resulting accumulation of angiotensin II (Ang II) - worsens any preexisting cardiovascular disease, along with RAS dysregulation, leading to severe cases and deaths. ${ }^{11}$ Regardless, the potential role of the RAS in COVID-19 patients either with or without cardiovascular diseases cannot be overlooked, and a reasonable understanding of the crosstalk between COVID-19 and the RAS is almost essential for the ideal management of patients with cardiometabolic diseases. In the following review, we describe the imbalance of the classical RAS and counter-regulatory RAS axes in COVID-19 patients with cardiovascular metabolic diseases and discuss the latest findings based on angiotensin-converting enzyme inhibitor (ACEI) and angiotensin II type 1 receptor blocker (ARB) administration and ACE-2 availability in relation to COVID-19.

\section{RAS}

\section{Classical axis: ACE/Ang II/angiotensin II type 1 receptor (AT1R)}

The RAS plays a pivotal role in the pathophysiology of cardiovascular diseases. Renin (angiotensinogenase) is secreted by the kidney, stimulating angiotensinogen to release angiotensin I (Ang I) peptide. Ang I is then converted to Ang II by ACE, which is expressed in high volumes by endothelial and epithelial cells in the vasculature, kidneys, heart, and lungs. ${ }^{12}$ Ang II is the major vasoactive peptide, playing a crucial role during normal or pathophysiologic conditions. ${ }^{3}$

The binding of Ang II to AT1R is common throughout the cardiovascular system and induces systemic vasoconstriction, proinflammatory and profibrotic effects, and aldosterone secretion. ${ }^{13}$ Activation of the ACE/Ang II/ AT1R axis induces apoptosis in alveolar epithelial cells, ${ }^{14}$ promotes ventilator-induced lung injury, ${ }^{15}$ increases lung microvascular permeability, ${ }^{16}$ stimulates proinflammatory cytokine release, and promotes macrophage and neutrophil chemotaxis associated with lung injuries. ${ }^{97}$ Moreover, the
19. Des essais cliniques urgents issus de différents pays et hôpitaux ont montré qu'il n'y avait pas d'association entre le traitement par inhibiteurs du SRA et les complications liées à l'infection par la COVID19 ou aux comorbidités. Néanmoins, la perturbation du SRA qui est associée à l'infection par la COVID-19 et le traitement potentiel dans ce champ restent à résoudre. Dans la présente revue, le lien entre la dysrégulation du SRA traditionnel et les activités contre-régulatrices du SRA chez les patients atteints de la COVID-19 qui ont des maladies cardiovasculaires métaboliques est étudié. De plus, nous nous penchons sur les plus récentes conclusions fondées sur l'administration des IECA et des ARA et la disponibilité de I'ECA2 en relation avec la COVID-19 pour offrir une meilleure compréhension de la contribution du SRA à la pathologie de la COVID-19, puisqu'ils sont de la plus haute importance dans le contexte de l'actuelle pandémie.

activation of the ACE/Ang II/AT1R axis stimulates both the adaptive and innate immune proinflammatory responses, leading to inflammation, autoimmune dysfunctions, and cardiovascular damage. ${ }^{18,19}$

\section{Counter-regulatory axes}

ACE-2/Angiotensin 1-7 (Ang 1-7) Mas receptor (MasR). Ang 1-7 is produced by cleavage of Ang I and II by neprilysin and ACE-2, respectively. ${ }^{20}$ The RAS regulatory effect of Ang 1-7 is imparted by its binding to the MasR. Ang 1-7 has been reported to play a protective role in cardiovascular diseases through its central control of blood pressure ${ }^{21}$ and by serving as an important neuromodulator in the central nervous system to control cardiovascular function and counteract Ang II effects. ${ }^{22}$ Ang 1-7 might also act as a local synergistic regulator of kinin-induced vasodilation via inhibiting the generation of ACE and nitric oxide. ${ }^{23}$

During vascular inflammation, Ang 1-7 decreases monocyte chemoattractant protein-1 (MCP-1), interleukin-6 (IL6), tumor necrosis factor alpha (TNF- $\alpha$ ), nuclear factor kappa-B, vascular cell adhesion protein 1 , reactive oxygen species levels, and apoptosis. ${ }^{24}$ Furthermore, activation of angiotensin II type 2 receptor (AT2R) via Ang 1-7 stimulation prevents inflammation and cardiac hypertrophy, as well as reducing vascular remodeling and alveolar septum thickness, which - in a rat with chronic lung disease-protects the heart and lungs from damage. ${ }^{25}$

Ang 1-7 can also be a source of another counter-regulatory renin-angiotensin pathway when produced from Ang II by ACE-2 and then transformed to alamandine. ${ }^{26}$ Alternatively, Ang II can be transformed to angiotensin A (Ang A) by aspartate decarboxylase. Ang A can be converted to alamandine by ACE-2. Recently discovered as part of RAS regulation, alamandine-via binding to Mas-related G protein-coupled receptor member $\mathrm{D}(\mathrm{MrgD})$ - promotes antihypertensive and cardioprotective effects similar to those of Ang 1-7.27,28

ACE2/Ang 1-9/AT2R. It was demonstrated in the rat model that angiotensin 1-9 (Ang 1-9) has a cardioprotective effect resulting from the activation of AT2R, improving endothelial function, fibrosis, oxidative stress, collagen deposition, ${ }^{29}$ and cardiac hypertrophy, ${ }^{30}$ and protecting against cardiac ische$\mathrm{mia} /$ reperfusion injury. ${ }^{31}$ It was further reported that Ang 1-9 ameliorates pulmonary arterial hypertension via AT2R by decreasing apoptosis and plasmatic proinflammatory 
cytokines, such as TNF- $\alpha$, MCP-1, IL- $1 \beta$, and IL- $6 .{ }^{32}$ Independently of MasR or AT2R, Ang 1-9 protects against hypertension and cardiovascular damage by decreasing the inflammation in deoxycorticosterone acetate-salt rat test subjects. ${ }^{33}$ It was suggested that the Ang 1-9/AT2R axis has a protective effect in vasculature, preventing the heart and kidneys in patients with heart failure and/or hypertension from adverse cardiovascular remodeling. ${ }^{34,35}$

It has been observed in vivo that selective activation of AT2 receptors attenuates the progression of pulmonary hypertension and inhibits cardiopulmonary fibrosis. ${ }^{36}$ It has also been identified that the stimulation of AT2R using a selective agonist, compound 21 (C21), attenuates the progression of lung fibrosis and pulmonary hypertension in an experimental model of a bleomycin-induced lung injury ${ }^{37}$ while attenuating pulmonary inflammation in a model of acute lung injury. ${ }^{38}$

\section{Classical and Counter-Regulatory RAS Axes Interplay in Cardiometabolic and Pulmonary Diseases During SARS-CoV-2 Infection}

During pathophysiologic conditions, the ACE/Ang II/ AT1R axis is highly activated, yet it may be counter-regulated by the activation of the ACE-2/Ang 1-7/MasR and ACE-2/ Ang 1-9/AT2R axes. Pharmacologic inhibition of the ACE/ Ang II/AT1R axis using ACEIs or ARBs induced the upregulation of ACE-2 expression. ${ }^{39}$ It was found that ACE-2 inhibits the Ang II/AT1R axis via degradation of Ang I to Ang 1-9 and Ang II into Ang 1-7, which are active biologically through their receptors AT2 and MAS, respectively, and act as antiinflammatory vasodilators, and anti-fibrotic and anti-proliferative peptides. ${ }^{40-44}$ It was demonstrated that the SARS virus outbreak in 2003 was accompanied by a decrease in ACE-2 expression in the heart, ${ }^{45}$ which is posited by some to be the possible cause of the myocardial dysfunction and inflammation observed in COVID-19 patients.

During COVID-19 infection, the virus uses ACE-2 for cell entry, potentially disturbing RAS-induced homeostasis, while potentially also affecting the activity of the counter-regulatory RAS system dependent on ACE-2 availability. This action could, in turn, exaggerate the effects of COVID-19 infection, in terms of RAS homeostasis leading to cardiovascular and pulmonary complications.

Recently, it was reported that ACE-2 overexpression counter-regulates the inflammatory responses due to RAS activation, by maintaining the balance between the ACE-2/Ang 1-7/MasR and ACE/Ang II/AT1R axes associated with protective effects against lipopolysaccharide-induced acute lung injury in the mice model, ${ }^{46}$ as well as inhibiting the inflammatory response and oxidative stress. ${ }^{47}$ More recently, it was reported that the Ang 1-7/MasR axis mediates its anti-inflammatory effects in a murine model of asthma through Srcmediated epidermal growth factor receptor transactivation. ${ }^{48}$

In some COVID-19 cases, the immune response to the viral infection intensified due to the up-regulation of the ACE/Ang II/AT1R axis, accompanied by ACE-2 depletion, which increases the production of proinflammatory cytokines, leading to cytokine storm syndrome, which is associated with severe cases and death. ${ }^{49-51}$ Most of the deleterious effects following ACE/Ang II/AT1R axis activation that are associated with lung injuries, such as acute respiratory distress syndrome
(ARDS) and ventilator-induced lung injury, are prevented using RAS inhibitors (ACEIs and ARBs) or RAS regulators (AT2R agonist [C21], recombinant soluble human ACE-2 [rhACE-2], Ang 1-7, and MasR agonists; ${ }^{52,53}$ Fig. 1).

Moreover, the vast majority of protective peptides are dependent on ACE-2 enzyme activity, with this enzymatic pathway representing an endogenous negative regulator of RAS activation. SARS-CoV-2 enters cells via an interaction with ACE- $2,{ }^{54}$ which is highly expressed in coronary endothelial cells, cardiomyocytes, and cardiac fibroblasts. ${ }^{55}$ Furthermore, ACE-2 has been recognized as a major RAS regulator, able to alleviate the deleterious effects mediated by Ang II and AT1 R. ${ }^{56}$ Current studies on angiotensin peptides such as Ang 1-7, angiotensin 2-8, Ang 1-9, angiotensin 3-7, and angioten$\sin 3-8$ are vital in counteracting the deleterious effects of Ang II. ${ }^{57}$ Interestingly, in the midst of ACE-2 deficiency, protective Ang 1-7 can be produced independently of ACE-2, either from Ang I via neprilysin, thimet oligopeptidase, or prolyl oligopeptidase, or it can be produced from Ang-II via prolyl carboxypeptidase, or prolyl oligopeptidase, favoring a tilt toward the protective Ang1-7/MasR axis ${ }^{58,59}$ (Fig. 1).

Additionally, it has been strongly suggested that ACE-2 deficiency resulting from SARS-CoV-2 binding leads to an increase in bradykinin and des-Arg ${ }^{9}$-bradykinin levels, which in turn causes difficulties seen during COVID-19 infection, such as pulmonary edema, ${ }^{60}$ pneumonia, and respiratory failure. ${ }^{61}$ Thimet oligopeptidase and prolyl carboxypeptidase are known to be expressed in endothelial cells and to contribute to the metabolism of bradykinin and des-Arg' ${ }^{9}$-bradykinin, respectively. ${ }^{59,62,63}$

Moreover, in addition to the ability of prolyl oligopeptidase to produce antifibrotic and anti-inflammatory Ang 1-7, it can convert thymosin $\beta 4$ to $\mathrm{N}$-acetyl-seryl-aspartyl-lysylproline (AC-SDKP), which provides an anti-inflammatory and antifibrotic effect in lung and cardiovascular diseases. ${ }^{64}$ Activation of the ACE2 compensatory pathways during COVID-19 infection could potentially do the following: (i) cause an increase in Ang 1-7 production from accumulated Ang I and Ang II, in order to reconcile the RAS balance; (ii) result in the degradation of bradykinin and des-Arg ${ }^{9}$-bradykinin via the actions of thimet oligopeptidase and prolyl carboxypeptidase, respectively, for the purpose of managing or alleviating pulmonary edema and respiratory failure; and (iii) support Ang 1-7 function by increasing AC-SDKP production and reducing Ang-II accumulation.

\section{Cardiometabolic and Pulmonary Diseases During CoVID-19 Infection}

COVID-19 has an acutely harmful effect on patients with cardiovascular diseases. The volume of severe cases and high mortality rates noted in COVID-19 patients are closely correlated with cardiovascular metabolic comorbidities, such as hypertension, cardiovascular diseases, and diabetes. ${ }^{65}$ COVID-19 can aggravate any damage to the heart and significantly increase the incidence of acute cardiac injury in intensive care unit/severe patients. ${ }^{65}$ Additionally, elevated levels of creatine kinase and lactate dehydrogenase have been reported in COVID-19 patients. ${ }^{66,67}$ Wang et al. also found arrhythmia and elevated hypersensitive troponin I in 138 COVID19 patients at Zhongnan Hospital in Wuhan, ${ }^{68}$ which might 


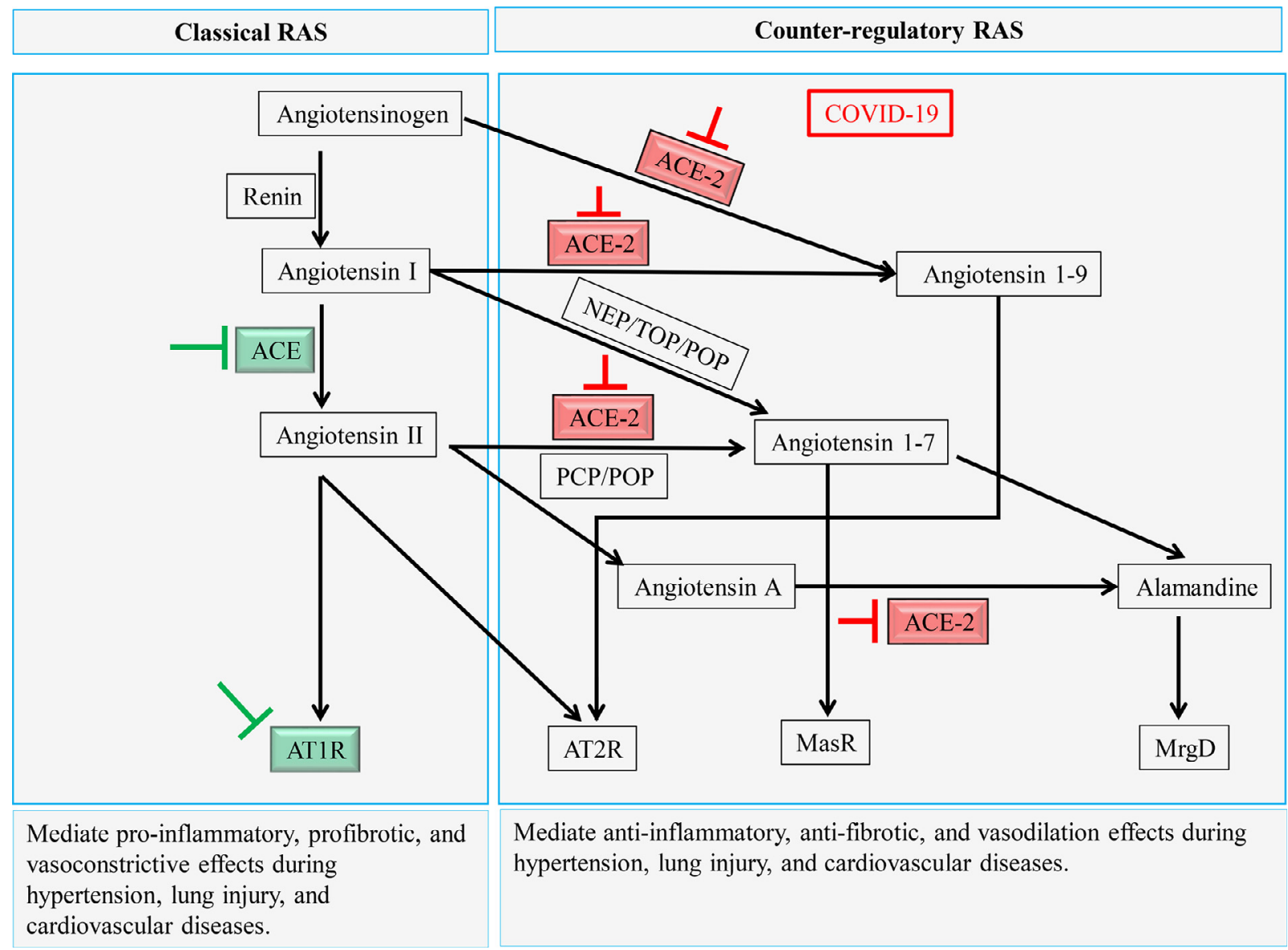

Figure 1. Summary of renin-angiotensin system (RAS) axes contribution and RAS inhibitor effect during COVID-19 infection. The green arrows indicate classical RAS inhibition by angiotensin-converting enzyme inhibitors (ACEIs) and angiotensin II type 1 receptor blockers. The red arrows indicate the inhibition caused by COVID-19. AT1R, angiotensin II type 1 receptor; AT2R, angiotensin II type 2 receptor, MasR, Mas receptor, MrgD, Mas-related G protein-coupled receptor member D; NEP, neprilysin; PCP, prolyl carboxypeptidase; POP, prolyl oligopeptidase; TOP, thimet oligopeptidase.

be due to SARS-CoV-2 infection-induced lung failure, cytokine storm, or decreased oxygenation.

According to available clinical data from China, $2.5 \%$ to $15 \%$ of COVID-19 patients also have cardiovascular diseases, and $15 \%$ to $30 \%$ also have hypertension. ${ }^{55,66}$ These values are variable across countries, and in Italy, according to recent clinical data, the percentage of patients with COVID-19 who also have hypertension (46\%-52\%), cardiovascular disease (19\%-24\%), and hypercholesterolemia (16\%-20\%) is much higher. ${ }^{69}$ All these clinical features share a common disorder of RAS activity, wherein the classical RAS is highly activated, leading to an increase in Ang II and upregulation of the ACE/ Ang II/AT1R axis.

A recent study by Osman et al. ${ }^{70}$ exemplified that RAS components were modulated by SARS-CoV-2 in 44 COVID19 patients. ACE-2 expression was decreased in the blood cells and Ang I and Ang II were increased in the plasma. At the same time, the Ang 1-7 level, which is supposed to be low, was not significantly changed compared to that in the control samples, where it could be explained by the activation of ACE-2 independent of Ang 1-7 production pathways as a result of Ang I accumulation. That was not, however, enough to prevent the detrimental effects of Ang II accumulation. ${ }^{7}$
In order to counteract the deleterious effect of Ang II, the RAS is regulated either endogenously by negative feedback to reduce renin secretion ${ }^{71}$ or stimulation of AT2R, ${ }^{41}$ or exogenously by using ARBs, renin inhibitors, and ACEIs, which are the main drugs used to treat hypertension and vascular diseases. $^{72,73}$

\section{Myocardial injuries}

Ang 1-7 acts as an antiarrhythmic component in rat cardiac injury-reperfusion, which contributes to the alleviation of reversible and/or irreversible ischemia-reperfusion injury, ${ }^{74}$ activates the sodium pump, hyperpolarizes the heart cell, and re-establishes impulse conduction. ${ }^{75}$ Moreover, alamandine via the $\mathrm{MrgD}$ receptor stimulates the adenosine monophosphate-activated protein kinase pathway to alleviate cardiac hypertrophy that is induced by Ang II in alamandine-treated cardiomyocytes from a C57BL/6 mouse model. ${ }^{76}$ In the transverse aortic constriction mouse model, the oral administration of alamandine for 2 weeks prevented vascular remodelling and attenuated vascular wall fibrosis. In addition, alamandine was able to elevate $\mathrm{MrgD}$ receptor expression and attenuate AT1R expression induced by transverse aortic constriction. 
In the case of COVID-19, acute cardiac injury, ischemic stroke, acute coronary syndromes, myocarditis, arrhythmias, and heart failure were reported in hospitalized patients. ${ }^{78-80}$ High expression of ACE-2 in heart tissue, cytokine storm, and viral infection-associated hypoxemia are the main potential causes of COVID-19-associated myocardial injury. ${ }^{\text {8,79 }}$

Recently, it was found that SARS-CoV-2 infected the cardiomyocytes in an engineered human heart tissue model of COVID-19 with severe myocarditis, leading to contractile deficits, cytokine production, and cell death. ${ }^{81}$ Moreover, critically ill COVID-19 patients showed intense inflammatory syndrome and cardiac complications such as arrhythmia and myocarditis after 1 week of the infection, whereas deceased patients showed acute cardiac injury, type I respiratory failure, heart failure, and acute kidney injury. Acute cardiac injury and heart failure were especially common among these COVID-19 cases. $^{82-84}$

Increasing interleukin, leukocyte, and neutrophil levels in patients with myocardial injury was correlated with the severity of inflammation during COVID-19. ${ }^{85}$ As a result, the administration of alamandine may have therapeutic potential through antifibrotic and anti-inflammatory effects, to compensate for the effect of ACE-2 deficiency in cardiovascular diseases during COVID-19 infection. Additionally, ARBstelmisartan and olmesartan-demonstrated an anti-inflammatory effect in an experimental rat model of autoimmune myocarditis via the reduction of TNF- $\alpha$, interferon gamma, IL$1 \beta$, IL-6 proinflammatory cytokines, and increasing antiinflammatory cytokine IL-10 associated with less myocardial fibrosis. ${ }^{86,87}$

\section{Blood thrombosis and embolism}

Disseminated intravascular coagulation and pulmonary embolisms were detected in COVID-19 patients. ${ }^{9}$ Furthermore, increasing D-dimer and fibrinogen levels in COVID19 patients indicates thrombotic formation, and the endothelial damage produced by SARS-CoV-2 infection promotes the coagulation process that leads to the microthrombi formation. They can travel through blood vessels to different internal organs, resulting in pulmonary embolisms in addition to heart, kidney, and liver ischemic injuries. Moreover, frequent activation of the coagulation process-referred to as COVID19 coagulopathy-leads to poor outcomes and high mortality rates. ${ }^{82,88-91}$ The elevation of proinflammatory cytokines and chemokines during COVID-19 inhibits anticoagulation pathways, thus promoting thrombin formation..$^{92}$ Recently, high levels of Ang II were detected in COVID-19 patients, possibly contributing to the thrombosis seen in COVID-19 patients, ${ }^{93}$ whereas Ang 1-7 is posited to have an antithrombotic effect similar to that of losartan, ${ }^{94}$ mediating the antithrombotic effect of captopril in addition to that of losartan. ${ }^{95}$

\section{Obesity and diabetes}

In obese individuals, dysfunctional adipose tissue secretes proinflammatory cytokines in the circulatory system, contributing to obesity-related chronic inflammation. SARS-CoV-2 entry via the expression of ACE- 2 on adipose tissue could direct adipocytes to produce more proinflammatory cytokines, therefore contributing to the immune dysfunction seen during COVID-19 infection. In addition, IL-6 was identified as being more elevated in COVID-19 patients who also have diabetes - particularly compared to nondiabetic patientsputting them at risk of forming a deadly uncontrolled cytokine storm due to the damage of islets and pancreatic injury caused by SARS-CoV-2 entry. ${ }^{96}$ Moreover, diabetes increases the risk of death in COVID-19 patients fourfold, compared to the risk in COVID-19 patients without diabetes. ${ }^{97}$ In a Korean cohort observational study of 1082 COVID-19 patients, diabetes mellitus was found to be a risk factor for COVID-19 severity and mortality. ${ }^{98}$

The activation of the RAS plays a crucial role in inflammation, with the bulk of this system's proinflammatory function being due to Ang II and, more specifically, mediation by AT1R. AT1R, present in most cells, is stimulated by Ang II and activates targeted cells, as well as downstream signaling pathways associated with tissue injury and the inflammatory microenvironment, including fibrosis, oxidative stress, calcium mobilization, adaptive immune cell recruitment, neutrophils and monocyte adhesion, cytokines and chemokines expression, synthesis, and release. ${ }^{18,99-101}$ It was demonstrated that most of these effects are negatively regulated by the ACE2/Ang 1-7/MasR axis, ${ }^{102-106}$ which serves as a beneficial antiinflammatory axis in several inflammatory conditions associated with RAS activation and adipokine dysregulation, such as obesity, type 2 diabetes, and cardiovascular diseases. ${ }^{24}$ In a model of high-fat, diet-induced obesity, ACE-2 deficiency worsens epicardial adipose tissue inflammation, cardiac dysfunction, myocardial lipotoxicity, and cardiac insulin resistance. ${ }^{107}$ In obese patients, the administration of Ang 1-7 improved insulin-stimulated, endothelium-dependent vasodilation and blunted the vasoconstrictor effect of endothelin-1, which may counteract the hemodynamic abnormalities of human obesity. ${ }^{108}$

\section{Lung injuries}

It has been reported that up to $20 \%$ of COVID-19 patients suffer from respiratory diseases such as ARDS ${ }^{66-68}$ that are characterized by severe hypoxia, accumulation of inflammatory cells, and increased vascular permeabilitydependent pulmonary edema. ${ }^{109,110}$ ACE/Ang II/AT1R activation and/or expression is significantly upregulated in patients with sepsis, one of the most common causes of ARDS. Furthermore, pneumonia that is closely associated with infections such as SARS coronavirus ${ }^{111,112}$ or human influenza viruses ${ }^{113}$ is a predisposing factor for ARDS.

Ageing and ARDS are known to be lung fibrosis risk factors, with the 2 being identified together in the vast majority of COVID-19 cases. During the inflammatory phase of ARDS, matrix metalloproteinases are produced to contribute to lung injury and fibroproliferation. This process is followed by the production of IL- 6 , TNF- $\alpha$, and vascular endothelial growth factor, which are implicated in the ARDS conversion to fibrosis. Most COVID-19 patients with ARDS die due to the development of pulmonary fibrosis, which typically occurs in the first to third week of infection, and it is in most of the tissues of deceased patients. Therefore, the importance of anti-fibrotic intervention to counteract early-onset ARDS has been raised. ${ }^{114,115}$ The ACE-2/Ang 1-7/MasR axis protects against lung fibrosis by inhibiting Ang II-induced apoptotic 
Table 1. Summary of clinical studies and trials associated with hypertension and angiotensin-converting enzyme inhibitor/angiotensin II type 1 receptor blocker administration in relation to COVID-19 infection

\begin{tabular}{|c|c|c|c|c|c|c|}
\hline Study & Study type & Race or population & Mean age, $y$ & Sex & Sample size & Presence of comorbidity \\
\hline Mancusi et al. ${ }^{133}$ & $\begin{array}{l}\text { Observational study } \\
\text { (accession no.: } \\
\text { NCT04331574) }\end{array}$ & Italian & $67.9 \pm 15.6$ & Male, $62 \%$ & 1498 & Hypertension, HF \\
\hline Iaccarino et al. ${ }^{134}$ & $\begin{array}{l}\text { Observational study } \\
\text { (accession no.: } \\
\text { NCT04331574) }\end{array}$ & Italian & $66.5 \pm 0.4$ & Male, 65\% & 1591 & $\begin{array}{l}\text { Hypertension, DM, } \\
\text { COPD, CAD, HF, } \\
\text { obesity, CKD }\end{array}$ \\
\hline Semenzato et al. ${ }^{135}$ & Retrospective cohort & French & $49 \pm 31$ & Male, $42.3 \%$ & 2 million & $\begin{array}{l}\text { Only hypertension without } \\
\text { cardiovascular or } \\
\text { respiratory diseases }\end{array}$ \\
\hline Russo et al. ${ }^{136}$ & $\begin{array}{l}\text { Observational, } \\
\text { retrospective }\end{array}$ & Italian & $54 \pm 17$ & Male, 55\% & 351 & $\begin{array}{l}\text { Hypertension, AF, } \\
\text { dyslipidemia, DM, } \\
\text { CAD, COPD, CKD }\end{array}$ \\
\hline Genet et al. ${ }^{137}$ & Observational retrospective & French & $86.3 \pm 8$ & Male, 33\% & 201 & $\begin{array}{l}\text { Hypertension, dementia, } \\
\text { cancer, stroke, HF, AF, } \\
\text { CAD, COPD, DM, } \\
\text { depression, anemia, } \\
\text { malnutrition }\end{array}$ \\
\hline Zhong et al. ${ }^{138}$ & Retrospective observational & Chinese & $66.3 \pm 10.6$ & Male, $44.4 \%$ & 126 & $\begin{array}{l}\text { DM, CAD, COPD, CVD, } \\
\text { malignant tumours, } \\
\text { chronic hepatorenal } \\
\text { disease }\end{array}$ \\
\hline Palazzuoli et $\mathrm{al}^{139}$ & $\begin{array}{l}\text { Retrospective observational } \\
\text { cohort }\end{array}$ & Italian & $69 \pm 9$ & Male, $63.8 \%$ & 781 & $\begin{array}{l}\text { Hypertension, DM, OLD, } \\
\text { HF, CAD }\end{array}$ \\
\hline de Castelnuovo et al. ${ }^{140}$ & $\begin{array}{l}\text { Retrospective observational } \\
\text { (accession no: } \\
\text { NCT04318418) }\end{array}$ & Italian & $67 \pm 12$ & Male, $61.7 \%$ & 4069 & $\begin{array}{l}\text { Hypertension, IHD, DM, } \\
\text { cancer, CKD, CPD }\end{array}$ \\
\hline Negreira-Caamaño et al. ${ }^{141}$ & Observational cohort & Spanish & $76.5 \pm 12.3$ & Male, $51.9 \%$ & 545 & $\begin{array}{l}\text { Hypertension, DM, } \\
\text { obesity, lung disease, } \\
\text { COPD, asthma, OSAS, } \\
\text { HF, reduced LVEF, } \\
\text { IHD, AF, CKD, cancer }\end{array}$ \\
\hline Reynolds et al. ${ }^{142}$ & Observational & $\begin{array}{l}\text { Black, } 15 \% \text {; White, } \\
\text { 46.5\%; Asian, } 8.8 \% \text {; } \\
\text { other, } 29.6 \%\end{array}$ & $49 \pm 15$ & Male, $41.5 \%$ & 12,594 & $\begin{array}{l}\text { Hypertension, HF, DM, } \\
\text { MI, CKD, OLD }\end{array}$ \\
\hline Bauer et al. ${ }^{143}$ & Observational & $\begin{array}{l}\text { Black, } 11 \% \text {; White, } 53 \% \text {; } \\
\text { unknown, } 31 \% \text {; other, } \\
5 \%\end{array}$ & $54.7 \pm 22.5$ & Male, 37\% & 1449 & $\begin{array}{l}\text { Hypertension, chronic } \\
\text { respiratory disease, DM, } \\
\text { arterial disease, HF, } \\
\text { CKD, cancer, CLD }\end{array}$ \\
\hline Meng et al. ${ }^{144}$ & Retrospective observational & Chinese & $62 \pm 7$ & Male, $57.1 \%$ & 42 & $\begin{array}{l}\text { Hypertension, } \\
\text { hypothyroidism, DM, } \\
\text { cancer, atrioventricular } \\
\text { block, Sjogren's } \\
\text { syndrome, CHD }\end{array}$ \\
\hline Soleimani et al. ${ }^{145}$ & Retrospective observational & Iranian & $66.4 \pm 12.9$ & Male, $58.7 \%$ & 254 & $\begin{array}{c}\text { Hypertension, cardiac } \\
\text { disease, DM, CKD, } \\
\text { CVD, chronic lung } \\
\text { disease, malignancy }\end{array}$ \\
\hline Matsuzawa et al. ${ }^{146}$ & Retrospective observational & Japanese & $60 \pm 19$ & Male, $59.6 \%$ & 151 & $\begin{array}{l}\text { Hypertension, DM, } \\
\text { COPD, CKD, HF, } \\
\text { stroke }\end{array}$ \\
\hline Gao et al. ${ }^{147}$ & Retrospective observational & Chinese & $58 \pm 17$ & Male, $51 \%$ & 2877 & $\begin{array}{l}\text { Hypertension, DM, MA, } \\
\text { MI, peripheral vascular } \\
\text { disease, HF, renal failure, } \\
\text { stroke, COPD, } \\
\text { pneumonia, asthma, } \\
\text { cancer, OSAS }\end{array}$ \\
\hline Vila-Corcoles et al. ${ }^{148}$ & Retrospective observational & Spanish & $70 \pm 20$ & Male, $40.5 \%$ & 205 & $\begin{array}{l}\text { Hypertension, neurologic, } \\
\text { rheumatic, renal, liver, } \\
\text { respiratory, cardiac } \\
\text { diseases, AF, cancer, } \\
\text { hypercholesterolemia, } \\
\text { DM }\end{array}$ \\
\hline Desai et al. ${ }^{149}$ & Retrospective observational & Italian & $64.8 \pm 14.5$ & Male, $66 \%$ & 575 & $\begin{array}{l}\text { Hypertension, respiratory, } \\
\text { and cardiovascular } \\
\text { diseases, DM, } \\
\text { malignancy }\end{array}$ \\
\hline Zhang et al. ${ }^{150}$ & Retrospective observational & Chinese & $62 \pm 7$ & Male, $53.5 \%$ & 1128 & $\begin{array}{l}\text { Hypertension, DM, CHD, } \\
\text { CLD, chronic renal } \\
\text { diseases, CVD, COPD }\end{array}$ \\
\hline
\end{tabular}


Table 1. (Continued)

\begin{tabular}{|c|c|c|c|c|c|c|}
\hline Study & Study type & Race or population & Mean age, $y$ & Sex & Sample size & Presence of comorbidity \\
\hline Mancia et al. ${ }^{151}$ & Retrospective observational & Italian & $68 \pm 13$ & Male, $63 \%$ & 6272 & $\begin{array}{l}\text { Hypertension, } \\
\text { cardiovascular disease, } \\
\text { CAD, HF, COPD, } \\
\text { respiratory disease, } \\
\text { asthma, CKD, cancer }\end{array}$ \\
\hline Li et al. ${ }^{152}$ & Retrospective observational & Chinese & 66 & Male, $52.2 \%$ & 362 & $\begin{array}{l}\text { Hypertension, CVD, DM, } \\
\text { CHD, HF, CKD, } \\
\text { digestive disorder, solid } \\
\text { tumours, respiratory } \\
\text { disease, neurologic } \\
\text { disease }\end{array}$ \\
\hline Lopes et al. ${ }^{153}$ & $\begin{array}{l}\text { Randomized clinical trial } \\
\text { (accession number: } \\
\text { NCT04364893) }\end{array}$ & Brazilian & 56 & Male, $60 \%$ & 659 & $\begin{array}{l}\text { Hypertension, CHD, DM, } \\
\text { cancer, asthma, HF, } \\
\text { kidney disease }\end{array}$ \\
\hline Cohen et al. ${ }^{154}$ & $\begin{array}{l}\text { Prospective randomized, } \\
\text { open-label trial } \\
\text { (accession number: } \\
\text { NCT04338009) }\end{array}$ & $\begin{array}{l}\text { Non-Hispanic Black, 13\%; } \\
\text { non-Hispanic White, } \\
\text { 16\%; Hispanic, } 53 \% \\
\text { other, } 17 \%\end{array}$ & $62 \pm 12$ & Male, $55 \%$ & 152 & $\begin{array}{l}\text { Hypertension, DM, } \\
\text { cardiac disease, HF, } \\
\text { IHD, AF, pulmonary } \\
\text { embolism, deep vein } \\
\text { thrombosis, OSAS, CPD }\end{array}$ \\
\hline
\end{tabular}

$\mathrm{AF}$, atrial fibrillation; $\mathrm{CAD}$, coronary artery disease; $\mathrm{CHD}$, coronary heart disease; $\mathrm{CKD}$, chronic kidney disease; CLD, chronic liver disease; COPD, chronic obstructive pulmonary disease; CPD, chronic pulmonary disease; CVD, cerebrovascular disease; DM, diabetes mellitus; HF, heart failure; IHD, ischemic heart disease; LVEF, left ventricle ejection fraction; MA, myocardial angina; MI, myocardial infarction; OLD, obstructive lung disease; OSAS, obstructive sleep apnea syndrome.

resistance of lung fibroblasts via the MAPK/ nuclear factor kappa-B pathway and activating the B-cell lymphoma-2 (BCL-2)-associated X protein/caspase-dependent mitochondrial apoptotic pathway. ${ }^{116,117}$ Interestingly, recent in silico studies noted that the combination of losartan-an ARBwith imatinib ${ }^{118}$ or $\mathrm{C} 21^{119}$ has the potential to alleviate ARDS during COVID-19 infection.

Increasing evidence has recently demonstrated the existence of local angiotensin systems in the alveolar endothelial cells of the lung. ${ }^{120}$ Ang II induces collagen deposition, nucleotide-binding oligomerization, domain-like receptor pyrin domain containing 3 (NLRP3) inflammasome activation, and oxidative stress that promotes pulmonary fibrosis. ${ }^{121,122}$ These effects were inhibited by ACE-2/Ang 1-7/MasR, which decreases lung fibroblast migration and lung fibrosis. ${ }^{122}$ The expression and activity of ACE- 2 are severely downregulated in both human and experimental lung fibrosis, suggesting that ACE-2 protects against lung fibrogenesis by limiting the local accumulation of the Ang II as a profibrotic peptide. ${ }^{{ }^{23}}$

Many COVID-19 patients have endothelial damage -induced inflammation, detected by increased production of inflammatory cytokines and chemokines such as TNF- $\alpha$, interferon gamma (IFN- $\gamma$ ), IL-2, IL-6, and IL-8. ${ }^{82,89,124}$ IL-6 acts as a crucial mediator of cytokine storm syndrome, resulting in lung damage and disseminated intravascular coagulation. ${ }^{125,126}$ Moreover, coronaviruses promote NLRP3, increasing the release of IL-18 and IFN- $\gamma$. IFN- $\gamma$ mediates acute lung injury and activates macrophages to release IL-18, IL-6, IL-8, IL-1, and MCP-1, which contribute to alveolar epithelial damage and acute lung injury. ${ }^{124,126}$

Ang II-induced acute lung injury was found to be attenuated by calcitriol/vitamin $\mathrm{D}$ receptor signals, reducing the expression of Ang II in endothelial cells and suppressing the Ang II-Tie-2- myosin light-chain kinase pathway in the acute lung injury mouse model. ${ }^{127}$ In a randomized clinical trial of 76 COVID-19 patients, all of whom were treated with a high dose of calcifediol, the severity of the disease decreased, as determined by a reduction of admissions to the intensive care unit. ${ }^{128}$ As Ang II is known to be elevated in patients with ARDS ${ }^{53}$ the most severe form of lung injury, it can be assumed that calcifediol can be converted to the active vitamin D3 (calcitriol), which blocks the Ang II inflammatory effect and alleviates ARDS in COVID-19 patients. To verify the discovery of calcifediol-indicated effects and their exact mechanisms, more clinical trials with larger numbers of test subjects are required.

\section{ACE-2 Expression and COVID-19}

Due to the propensity for patients under ACEI and ARB treatment to present with an upregulation of ACE-2, it was initially suggested that their conditions could be exacerbated by COVID-19. If this suggestion is correct, it renders a huge population of people under RAS inhibitor treatment at high risk, leading to a debate about the use of this medication. However, the upregulation of ACE- 2 in cardiac diseases such as myocardial infarction was considered to be a negative regulatory action in response to the increase of the activity of the $\mathrm{ACE} /$ Ang II/AT1R axis. Moreover, that upregulation was suggested to be part of ACE-2 involvement in the inflammatory response during myocardial infarction rather than being an ACEI or ARB direct effect. ${ }^{129}$

Interestingly, a high level of expression of ACE-2 in cardiovascular disorders is unlikely to be a risk factor for or responsible for COVID-19 severity. To the best of our knowledge, men/boys are at higher risk of COVID-19 compared to women/girls, but the level of ACE-2 expression was shown to be higher in Asian women/girls compared to Asian men/boys. ${ }^{130}$ Moreover, the ACE-2 expression level in type-2 diabetic patients tends to decrease as the disease progresses. At the same time, patients with most cardiovascular diseases and those with type-2 diabetes need intensive care once they have 
Role of Renin-Angiotensin System in COVID-19

Table 2. Continued summary of clinical studies and trials associated with hypertension and ACEI/ARB administration in relation to COVID-19 infection

\begin{tabular}{|c|c|c|c|}
\hline Antihypertensive drugs used (\% of population) & $\begin{array}{l}\text { Period of ACEI/ARB intake before COVID- } \\
19 \text { infection }\end{array}$ & Main outcomes & Reference \\
\hline ACEIs (35.4\%) /ARBs (29.7\%) & Unknown & $\begin{array}{l}\text { Administration of ACEIs/ARBs did not affect } \\
\text { chance of recovery in COVID-19 patients } \\
\text { with hypertension or heart failure }\end{array}$ & 133 \\
\hline ACEIs (21.9\%) /ARBs (19.3\%) & Not mentioned & $\begin{array}{l}\text { ACEIs/ARBs did not contribute to mortality } \\
\text { from COVID-19 }\end{array}$ & 134 \\
\hline ACEIs (30\%), ARBs (51\%). & $\geq 3$ mos before study conduction & $\begin{array}{l}\text { ACEI/ARB administration lowered risk of } \\
\text { hospitalization and intubation or death with } \\
\text { COVID-19 compared to calcium-channel } \\
\text { blocker administration; } \\
\text { long-term use of ACEIs/ARBs might } \\
\text { decrease risk of COVID-19 in hypertensive } \\
\text { patients }\end{array}$ & 135 \\
\hline ACEIs/ARBs (26.78\%) & Not mentioned & $\begin{array}{l}\text { Most COVID-19 patients who did not require } \\
\text { hospitalization were hypertensive patients } \\
\text { and/or ACEI/ARB users }\end{array}$ & 136 \\
\hline ACEIs/ARBs (31.34\%) & $\geq 1$ wk before the onset of infection & $\begin{array}{l}\text { ACEI/ARB administration, before onset of } \\
\text { infection, significantly lowered mortality rate } \\
\text { in COVID-19 patients }\end{array}$ & 137 \\
\hline ACEIs/ARBs (29.37\%) & Not mentioned & $\begin{array}{l}\text { ACEI/ARB therapy did not contribute to } \\
\text { mortality in COVID-19 patients with } \\
\text { hypertension }\end{array}$ & 138 \\
\hline ACEIs (21.9\%)/ ARBs (17\%) & Not mentioned & $\begin{array}{l}\text { Previous use of ACEIs/ARBs reduced risk of } \\
\text { mortality in patients hospitalized with } \\
\text { COVID-19 infection }\end{array}$ & 139 \\
\hline $\begin{array}{l}\text { ACEIs }(13.5 \%) \text {; ARBs }(13.3 \%) \text {; both ACEIs } \\
\text { and ARBs }(0.4 \%)\end{array}$ & Not mentioned & $\begin{array}{l}\text { No association between ACEI/ARB usage and } \\
\text { severity or mortality in all COVID-19 } \\
\text { patients }\end{array}$ & 140 \\
\hline ACEI/ARB (30.8\%) & $\geq 1$ mo before hospital admission & $\begin{array}{l}\text { ACEI/ARB administration reduced risk of } \\
\text { death during hospitalization in COVID-19 } \\
\text { hypertensive patients }\end{array}$ & 141 \\
\hline $\begin{array}{l}\text { ACEIs }(8.3 \%) \text {; ARBs }(10.5 \%) \text {; ACEIs or } \\
\text { ARBs }(18.4 \%)\end{array}$ & Within 18 mos before COVID-19 diagnosis & $\begin{array}{l}\text { No association between ACEI/ARB treatment } \\
\text { and susceptibility to or severity of COVID- } \\
19 \text { infection }\end{array}$ & 142 \\
\hline ACEIs/ARBs (16\%) & Within 12 mos before COVID-19 test & $\begin{array}{l}\text { Previous use of ACEIs/ARBs had no effect on } \\
\text { severity of COVID-19 infection }\end{array}$ & 143 \\
\hline ACEIs/ARBs (40.5\%) & For $>1$ y & $\begin{array}{l}\text { ACEI/ARB administration improved clinical } \\
\text { outcomes of COVID-19 patients with } \\
\text { hypertension }\end{array}$ & 144 \\
\hline ARBs $(48 \%)$ & $\geq 7 \mathrm{~d}$ after hospital admission & $\begin{array}{l}\text { ARB treatment did not worsen clinical } \\
\text { outcomes during COVID-19 infection in } \\
\text { hypertensive patients }\end{array}$ & 145 \\
\hline ACEIs (2\%); ARBs (12.6\%) & Not mentioned & $\begin{array}{l}\text { ACEI/ARB treatment reduced poor outcomes } \\
\text { in COVID-19 patients with hypertension }\end{array}$ & 146 \\
\hline ACEIs/ARBs (6.36\%) & Not mentioned & $\begin{array}{l}\text { No association between ACEI/ARB treatment } \\
\text { and risk of mortality in COVID-19 patients }\end{array}$ & 147 \\
\hline ACEIs (37.6\%)/ARBs (16.1\%) & Not mentioned & $\begin{array}{l}\text { No association between ACEI/ARB treatment } \\
\text { and risk of COVID-19 infection in } \\
\text { hypertensive patients }\end{array}$ & 148 \\
\hline ACEIs (14.4\%)/ARBs (12.3\%) & Not mentioned & $\begin{array}{l}\text { Unlike ARBs, ACEIs reduced mortality risk in } \\
\text { COVID-19 patients }\end{array}$ & 149 \\
\hline ACEIs (2.75\%)/ARBs (14\%) & Not mentioned & $\begin{array}{l}\text { Administration of ACEIs/ARBs reduced risk of } \\
\text { all-cause mortality in COVID-19 patients } \\
\text { with hypertension }\end{array}$ & 150 \\
\hline ACEIs (23.9\%)/ARBs (22.2\%) & $\geq 1$ prescription during 2019 & $\begin{array}{l}\text { No association between ACEI/ARB treatment } \\
\text { and risk of COVID-19 infection }\end{array}$ & 151 \\
\hline ACEIs/ARBs (31.8\%) & Not mentioned & $\begin{array}{l}\text { ACEIs/ARBs are not associated with severity or } \\
\text { mortality of COVID-19 patients with } \\
\text { hypertension }\end{array}$ & 152 \\
\hline ACEIs/ARBs (50.6\%) & Not mentioned & $\begin{array}{l}\text { Previous administration of ACEIs/ARBs had } \\
\text { no association with the number of days alive } \\
\text { and out of the hospital in mild COVID-19 }\end{array}$ & 153 \\
\hline ACEIs/ARBs (49.3\%) & Not mentioned & $\begin{array}{l}\text { ACEI/ARB administration had no effect on } \\
\text { severity and mortality of COVID-19 }\end{array}$ & 154 \\
\hline
\end{tabular}

ACEI, angiotensin-converting enzyme inhibitor; ARB, angiotensin II type 1 receptor blocker. 
COVID-19, regardless of the ACE-2 level before the COVID-19 infection. Therefore, the severity of their cases seems to be due to the fact that they are suffering from metabolic disorders, with the balance of the RAS having already shifted toward the ACE/Ang II/AT1R axis, and alongside that, the COVID-19 infection has augmented the ACE/Ang II/AT1R axis effect, which includes vasoconstriction, hypertension, inflammation, and myocardial hypertrophy. ${ }^{130}$

\section{ACEI and ARB Administration During the COVID-19 Pandemic}

Various clinical studies and trials have been performed on diverse populations and ages, as well as on those with a range of comorbidities (Table 1), in order to determine the association between ACEI/ARB administration and COVID-19 infection. Most of those studies highlighted the lack of relationship of hypertension or ACEI/ARB administration with the risk of COVID-19 infection, severity, mortality, poor outcomes, and even chance of recovery. Other studies indicate that previous administration of ACEIs/ARBs lowers the risk of COVID-19 infection, as well as the severity and mortality rate (Table 2). This controversy could be attributed to the presence of several competing factors, which were overcome in some studies but not in others, thus limiting the ability to determine the exact relationship of COVID-19 with the following factors: (i) missing information about patient lifestyle, body mass index, history of smoking, dose and period of ACEI/ARB intake, and ACE-2 activity and expression; (ii) the degree of hypertension and its duration, which directly relates to heart failure and, therefore, poor outcomes; (iii) the fact that the presence of participants aged 80 years and over could cause an underestimation of the effects of antihypertensive drugs, due to the correlation between COVID-19 severity and mortality in older age patients; (iv) adherence to antihypertensive drug intake prior to, or during, COVID-19 infection, which due to the nature of retrospective studies, is not fully guaranteed and was based on drug prescriptions recorded in the databases. Furthermore, it is challenging to isolate and analyze the effects of ACEIs and ARBs independently, as they are commonly used for several comorbidities such as diabetes mellitus, hypertension, and coronary artery disease. At the same time, selection bias cannot be completely excluded, even following statistical analysis such as propensity-score matching. This consideration means that randomized, controlled trials are a necessity in order to delineate the potential effect of ACEIs/ARBs on COVID-19 patients. Avoiding the aforementioned factors could help to limit bias in future studies.

Despite the relationship between ACE-2 expression level and susceptibility to or severity of COVID-19, ARB and ACEI administration should not be discontinued, as their detrimental effect has not been confirmed, so their administration at least will protect COVID-19 patients with metabolic disorders from life-threating consequences. ${ }^{130}$

Interestingly, in 2014, Deshotels and coworkers ${ }^{131}$ demonstrated the effect of increased Ang II level on ACE2 downregulation during hypertension. The Ang II treatment was able to internalize ACE- 2 receptor and promote ACE-2 ubiquitination through AT1R binding, and the AT1 receptor in the absence of Ang II was found to be complexed with ACE-2 to prevent ACE-2 internalization.

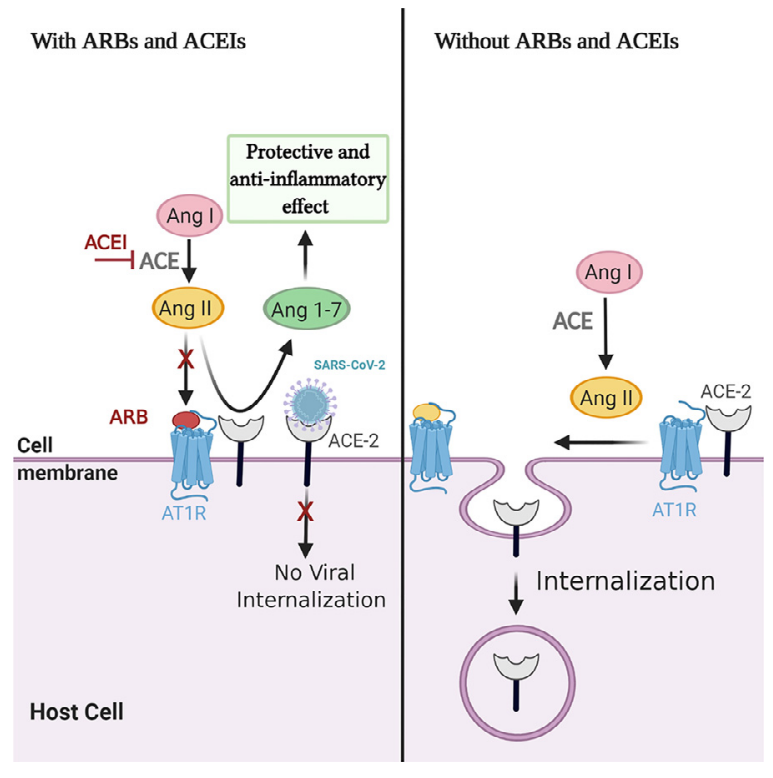

Figure 2. The effect of angiotensin (Ang) II treatment on angiotensinconverting enzyme (ACE)-2 downregulation in presence/absence of angiotensin II type 1 receptor blockers (ARBs) and angiotensin-converting enzyme inhibitors (ACEls). AT1R, angiotensin II type 1 receptor; SARS-CoV-2, severe acute respiratory syndrome coronavirus 2 . Created with BioRender.com.

Moreover, the absence of AT1R or AT1R blocking by losartan was found to attenuate the Ang II-mediated ACE-2 internalization. In the same context, ACEIs prevent Ang II production and upregulate Ang 1-7, which has an antiinflammatory effect. Hence, we posit that the use of ACEIs may protect against pulmonary injury, and ARBs -in particular, losartan-may prevent ACE-2 internalization and impede viral entry in hypertensive people with

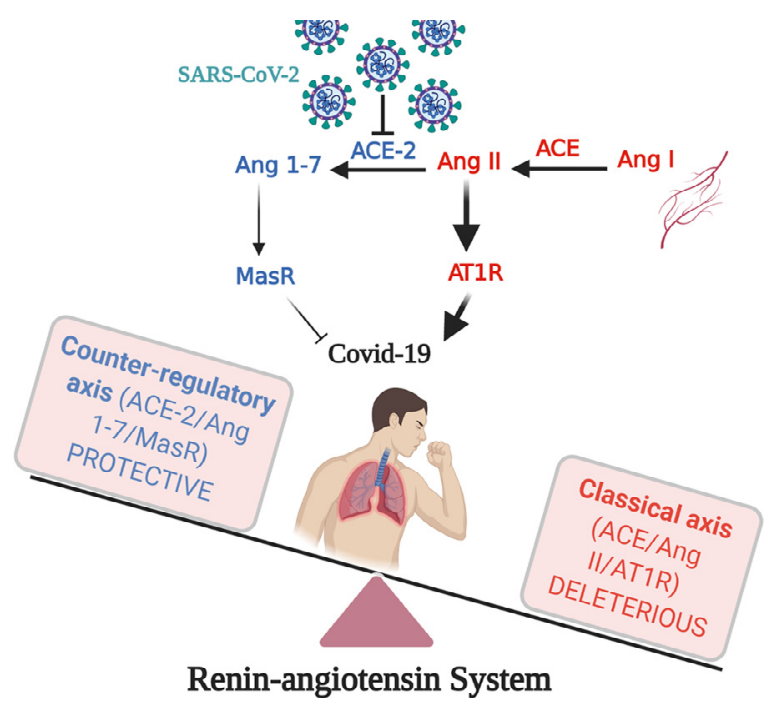

Figure 3. Dysregulation of classical and counter-regulatory renin -angiotensin system during COVID-19 infection. ACE, angiotensinconverting enzyme; Ang, angiotensin; AT1R, angiotensin II type 1 receptor; MasR, Mas receptor; SARS-CoV-2, severe acute respiratory syndrome coronavirus 2 . Created with BioRender.com. 
COVID-19. All these speculations need further investiga$\operatorname{tion}^{130,131}$ (Fig. 2).

In addition, the depletion of ACE-2 due to the SARSCov-2 binding in COVID-19 patients with respiratory problems increases the pulmonary injury. There is growing evidence to support the administration of $A R B s$ and ACEIs to activate the ACE-2/Ang 1-7/MasR axis, which ameliorates the deleterious effects of ACE-2 depletion and accelerates disease recovery. ${ }^{130}$ Thus, targeting the counter-regulatory RAS pathways could be of interest in explaining the association between COVID-19 and cardiometabolic diseases and could be a potential future target for treatment. Moreover, conducting randomized, controlled trials with large sample sizes is of utmost importance in order to determine the definitive effect of ACEI/ ARB administration on COVID-19 infection, and the pharmacologic mechanisms behind that effect.

\section{CoVID-19 Treatment}

The administration of several antiviral drugs that intervene with viral-host interaction has been under investigation as a possible COVID-19 treatment. ${ }^{132}$ For COVID-19 patients with ARDS, treatment with recombinant human ACE-2 (rhACE-2) is suggested as a possible strategy to maintain ACE- 2 availability and prevent viral-ACE-2 binding in the lung tissue by saturating SARS-CoV-2 spike protein in the blood before entry into the lung. In addition, the rhACE-2 may shift the balance toward the ACE-2/Ang 1-7/MasR axis, as activity of the latter was confirmed to increase after rhACE2 treatment. $^{8}$

As recommended by Rello et al. (2020), COVID-19 treatment by either antiviral, anti-inflammatory, anticoagulant, or antifibrotic agents can be personalized based on the main clinical phenotypes that occur in the patient. ${ }^{89}$ Ang 1-7 and Ang 1-9 can act as anti-inflammatory, anticoagulant, and antifibrotic factors, ${ }^{40}$ which can cover the majority of clinical phenotypes and thus potentially improve disease outcomes. In light of our hypothesis, the activation of Ang 1-7 without increasing ACE-2 activity may be a promising strategy to rebalance the RAS axes in COVID-19. For example, producing Ang 1-7 from Ang I through neprilysin activity will promote the protective effect of Ang 1-7 without stimulating ACE-2, which is known to be a virus entry portal.

In conclusion, COVID-19 patients share clinical phenotypes similar to those found in diseases where the ACE-2/Ang $1-7 / \mathrm{Mas} \mathrm{R}$ axis is downregulated, indicating the pivotal role of RAS balance during SARS-CoV-2 infection.

\section{Conclusion and Perspectives on the Future}

The main issue related to COVID-19 infection is the severity of the cases that lead to organ failure and death. In the majority of these cases, the patient is elderly, with at least one comorbidity factor. The majority of these comorbidities are related to cardiovascular diseases and risk factors. When infected with COVID-19, patients with cardiovascular diseases are most likely to develop new cardiac injuries, or worsen their existing pathologies. The RAS-as a crucial factor in cardiovascular diseases-will be disturbed during infection. This is because of the lack of ACE-2 function caused by virus binding and because of the potential imbalance of the RAS classical pathway activation (mainly ACE/Ang II/AT1R) and the RAS counter-regulatory pathway activation (mainly ACE2/Ang 1-7/MasR and ACE-2/Ang 1-9/AT2R; Fig. 3). Targeting the counter-regulatory pathways using agonists or stimulators, such as rhACE-2, MasR agonists, or AT2R agonists, may be of interest to boost the function of this system, or compensate for the poor ACE-2 functionality or availability, possibly due to virus binding, and, seems to be a promising therapeutic strategy for COVID-19 treatment.

\section{Acknowledgements}

The authors extend their appreciation to the medical core facility and research/funding platforms at King Abdullah International Medical Research Center (KAIMRC) for supporting and funding the project (RC20/153/R). The authors extend their appreciation to the Deanship of Scientific Research at King Saud University for funding this work through research group no. RG-1441-534.

\section{Funding Sources}

This review article was supported by a grant from King Abdullah International Research Center no. RC20/153/R.

\section{Disclosures}

The authors have no conflicts of interest to disclose.

\section{References}

1. Fernández-Ruiz I. Immune system and cardiovascular disease. Nat Rev Cardiol 2016;13:503.

2. Barhoumi T, Kasal DA, Li MW, et al. T regulatory lymphocytes prevent angiotensin II-induced hypertension and vascular injury. Hypertension 2011;57:469-76

3. Iulita MF, Duchemin S, Vallerand D, et al. CD4(+) regulatory T lymphocytes prevent impaired cerebral blood flow in angiotensin ii-induced hypertension. J Am Heart Assoc 2019;8:e009372.

4. Javeshghani D, Barhoumi T, Idris-Khodja N, Paradis P, Schiffrin EL. Reduced macrophage-dependent inflammation improves endothelin-1induced vascular injury. Hypertension 2013;62:112-7.

5. Wu CH, Mohammadmoradi S, Chen JZ, et al. Renin-angiotensin system and cardiovascular functions. Arterioscler Thromb Vasc Biol 2018;38:E108-16.

6. Shahid Z, Kalayanamitra R, McClafferty B, et al. COVID-19 and older adults: what we know. J Am Geriatr Soc 2020;68:926-9.

7. Dong G, Du Z, Zhu J, et al. The clinical characteristics and prognosis of COVID-19 patients with comorbidities: a retrospective analysis of the infection peak in Wuhan. Ann Transl Med 2021;9:280.

8. Rossi GP, Sanga V, Barton M. Potential harmful effects of discontinuing ACE-inhibitors and ARBs in COVID-19 patients. Elife 2020;9:1-8

9. Rafiq D, Batool A, Bazaz MA. Three months of COVID-19: a systematic review and meta-analysis. Rev Med Virol 2020;30:e2113.

10. World Health Organization. WHO Coronavirus Disease (COVID19) Dashboard. Available at: https://covid19.who.int/. Accessed June 14, 2020. 
11. Beyerstedt S, Casaro EB, Rangel ÉB. COVID-19: angiotensin-converting enzyme 2 (ACE2) expression and tissue susceptibility to SARSCoV-2 infection. Eur J Clin Microbiol Infect Dis 2021: 1-15. Jan 3.

12. Chawla LS, Chen S, Bellomo R, Tidmarsh GF. Angiotensin converting enzyme defects in shock: Implications for future therapy. Crit Care 2018;22:10-2.

13. Li XC, Zhang J, Zhuo JL. The vasoprotective axes of the renin-angiotensin system: physiological relevance and therapeutic implications in cardiovascular, hypertensive and kidney diseases. Pharmacol Res 2017;125:21-38.

14. Wang R, Zagariya A, Ibarra-Sunga O, et al. Angiotensin II induces apoptosis in human and rat alveolar epithelial cells. Am J Physiol 1999;276:L885-9.

15. Yao S, Feng D, Wu QP, Li KZ, Wang LK. Losartan attenuates ventilator-induced lung injury. J Surg Res 2008;145:25-32.

16. Chen C, Zhang Z, Li Z, et al. Losartan attenuates microvascular permeability in mechanical ventilator-induced lung injury in diabetic mice. Mol Biol Rep 2014;41:809-14.

17. Hagiwara S, Iwasaka H, Hidaka S, et al. Antagonist of the type-1 ANG II receptor prevents against LPS-induced septic shock in rats. Intensive Care Med 2009;35:1471-8.

18. Capettini LS, Montecucco F, Mach F, et al. Role of renin-angiotensin system in inflammation, immunity and aging. Curr Pharm Des 2012;18:963-70.

19. Caillon A, Mian MOR, Fraulob-Aquino JC, et al. $\gamma \delta$ T cells mediate angiotensin II-induced hypertension and vascular injury. Circulation $2017 ; 135: 2155-62$

20. Forrester SJ, Booz GW, Sigmund CD, et al. Angiotensin II signal transduction: an update on mechanisms of physiology and pathophysiology. Physiol Rev 2018;98:1627-738.

21. Fontes MAP, Silva LCS, Campagnole-Santos MJ, et al. Evidence that angiotensin-(1-7) plays a role in the central control of blood pressure at the ventro-lateral medulla acting through specific receptors. Brain Res 1994;665:175-80.

22. Xia H, Lazartigues E. Angiotensin-converting enzyme 2: central regulator for cardiovascular function. Curr Hypertens Rep 2010;12:170-5.

23. Li P, Chappell MC, Ferrario CM, Brosnihan KB. Angiotensin-(1-7) augments bradykinin-induced vasodilation by competing with ACE and releasing nitric oxide. Hypertension 1997;29:394-400.

24. Lelis D F, Freitas DF, Machado AS, Crespo TS, Santos SHS. Angiotensin-(1-7), adipokines and inflammation. Metabolism 2019;95:36-45.

25. Wagenaar GTM, Laghmani EH, Fidder M, et al. Agonists of MAS oncogene and angiotensin II type 2 receptors attenuate cardiopulmonary disease in rats with neonatal hyperoxia-induced lung injury. Am J Physiol Lung Cell Mol Physiol 2013;305:L341-51.

26. Paz Ocaranza M, Riquelme JA, García L, et al. Counter-regulatory renin-angiotensin system in cardiovascular disease. Nat Rev Cardiol $2020 ; 17: 116-29$.

27. Liu C, Yang CX, Chen XR, et al. Alamandine attenuates hypertension and cardiac hypertrophy in hypertensive rats. Amino Acids 2018;50: $1071-81$

28. Park BM, Phuong HTA, Yu L, Kim SH. Alamandine protects the heart against reperfusion injury via the $\mathrm{MrgD}$ receptor. Circ J 2018;82: 2584-93.

29. Ocaranza MP, Moya J, Barrientos V, et al. Angiotensin-(1-9) reverses experimental hypertension and cardiovascular damage by inhibition of the angiotensin converting enzyme/Ang II axis. J Hypertens 2014;32:771-83.

30. Ocaranza MP, Lavandero S, Jalil JE, et al. Angiotensin-(1-9) regulates cardiac hypertrophy in vivo and in vitro. J Hypertens 2010;28:1054-64.

31. Mendoza-Torres E, Riquelme JA, Vielma A, et al. Protection of the myocardium against ischemia/reperfusion injury by angiotensin-(1-9) through an AT 2 R and Akt-dependent mechanism. Pharmacol Res 2018;135:112-21.

32. Cha SA, Park BM, Kim SH. Angiotensin-(1-9) ameliorates pulmonary arterial hypertension via angiotensin type II receptor. Korean J Physiol Pharmacol 2018;22:447-56.

33. Gonzalez L, Novoa U, Moya J, et al. Angiotensin-(1-9) reduces cardiovascular and renal inflammation in experimental renin-independent hypertension. Biochem Pharmacol 2018;156:357-70.

34. Ocaranza MP, Michea L, Chiong M, et al. Recent insights and therapeutic perspectives of angiotensin-(1-9) in the cardiovascular system Clin Sci (Lond) 2014;127:549-57.

35. Ocaranza MP, Jalil JE. Protective role of the ACE2/Ang-(19) axis in cardiovascular remodeling. Int J Hypertens 2012;2012:594361.

36. Bruce E, Shenoy V, Rathinasabapathy A, et al. Selective activation of angiotensin AT2 receptors attenuates progression of pulmonary hypertension and inhibits cardiopulmonary fibrosis. $\mathrm{Br} \mathrm{J}$ Pharmacol 2015;172:2219-31.

37. Rathinasabapathy A, Horowitz A, Horton K, et al. The selective angiotensin II type 2 receptor agonist, compound 21, attenuates the progression of lung fibrosis and pulmonary hypertension in an experimenta model of bleomycin-induced lung injury. Front Physiol 2018;9:1-11.

38. Menk M, Graw JA, Von Haefen C, et al. Angiotensin II type 2 receptor agonist compound 21 attenuates pulmonary inflammation in a model of acute lung injury. J Inflamm Res 2018;11:169-78.

39. Ferrario CM, Jessup J, Chappell MC, et al. Effect of angiotensin-converting enzyme inhibition and angiotensin II receptor blockers on cardiac angiotensin-converting enzyme 2. Circulation 2005;111:2605-10.

40. Anguiano L, Riera M, Pascual J, Soler MJ. Circulating ACE2 in cardiovascular and kidney diseases. Curr Med Chem 2017;24:3231-41.

41. de Gasparo M, Catt KJ, Inagami T, Wright JW, Unger T. International Union of Pharmacology. XXIII. The angiotensin II receptors. Pharmacol Rev 2000;52:415-72.

42. Mercure C, Yogi A, Callera GE, et al. Angiotensin(1-7) blunts hypertensive cardiac remodeling by a direct effect on the heart. Circ Res 2008;103:1319-26.

43. Bader M. ACE2, angiotensin-(1-7), and Mas: the other side of the coin. Pflugers Arch Eur J Physiol 2013;465:79-85.

44. Alenina N, Xu P, Rentzsch B, Patkin EL, Bader M. Genetically altered animal models for Mas and angiotensin-(1-7). Exp Physiol 2008;93: $528-37$.

45. Oudit GY, Kassiri Z, Jiang C, et al. SARS-coronavirus modulation of myocardial ACE2 expression and inflammation in patients with SARS. Eur J Clin Invest 2009;39:618-25.

46. Ye R, Liu Z. ACE2 exhibits protective effects against LPS-induced acute lung injury in mice by inhibiting the LPS-TLR4 pathway. Exp Mol Pathol 2020;113:104350.

47. Fang Y, Gao F, Liu Z. Angiotensin-converting enzyme 2 attenuates inflammatory response and oxidative stress in hyperoxic lung injury by regulating NF-jB and Nrf2 pathways. QJM 2019;112:914-24. 
48. El-Hashim AZ, Khajah MA, Babyson RS, et al. Ang-(1-7)/MAS1 receptor axis inhibits allergic airway inflammation via blockade of Srcmediated EGFR transactivation in a murine model of asthma. PLoS One 2019;14:1-22.

49. Gheblawi M, Wang K, Viveiros A, et al. Angiotensin-converting enzyme 2: SARS-CoV-2 receptor and regulator of the renin-angiotensin system: celebrating the 20th anniversary of the discovery of ACE2. Circ Res 2020:1456-74

50. Lanza K, Perez LG, Costa LB, et al. Covid-19: the renin-angiotensin system imbalance hypothesis. Clin Sci (Lond) 2020;134:1259-64.

51. Rali AS, Ranka S, Shah Z, Sauer AJ. Mechanisms of myocardial injury in coronavirus disease 2019. Card Fail Rev 2020;6:e15.

52. Wang D, Chai X, Magnussen CG, Zosky GR, Shu S. Renin-angiotensin-system, a potential pharmacological candidate, in acute respiratory distress syndrome during mechanical ventilation. Pulm Pharmacol Ther 2019;58:101833.

53. Imai Y, Kuba K, Rao S, et al. Angiotensin-converting enzyme 2 protects from severe acute lung failure. Nature 2005;436:112-6.

54. Zhou P, Yang XL, Wang XG, et al. A pneumonia outbreak associated with a new coronavirus of probable bat origin. Nature 2020;579:270-3.

55. Guo J, Huang Z, Lin L, Lv J. Coronavirus disease 2019 (COVID-19) and cardiovascular disease: a viewpoint on the potential influence of angiotensin-converting enzyme inhibitors/angiotensin receptor blockers on onset and severity of severe acute respiratory syndrome coronavirus 2 infection. J Am Heart Assoc 2020;9:e016219.

56. Patel VB, Zhong J-C, Grant MB, Oudit GY. Role of the ACE2/angiotensin $1-7$ axis of the renin-angiotensin system in heart failure. Circ Res 2018;118:1313-26.

57. Arendse LB, Jan Danser AH, Poglitsch M, et al. Novel therapeutic approaches targeting the renin-angiotensin system and associated peptides in hypertension and heart failure. Pharmacol Rev 2019;71:539-70.

58. Grobe N, Weir NM, Leiva O, et al. Identification of prolyl carboxypeptidase as an alternative enzyme for processing of renal angiotensin II using mass spectrometry. Am J Physiol Cell Physiol 2013;304:945-53.

59. Ferrario CM, Iyer SN. Angiotensin-(1-7): a bioactive fragment of the renin-angiotensin system. Regul Pept 1998;78:13-8.

60. de Maat S, de Mast Q, Danser AHJ, van de Veerdonk FL, Maas C. Impaired breakdown of bradykinin and its metabolites as a possible cause for pulmonary edema in COVID-19 infection. Semin Thromb Hemost 2020;46:835-7.

61. Mansour E, Bueno FF, de Lima-Júnior JC, et al. Evaluation of the efficacy and safety of icatibant and C1 esterase/kallikrein inhibitor in severe COVID-19: study protocol for a three-armed randomized controlled trial. Trials 2021;22:1-13.

62. Norman M, Reeve S, Dive V, Smith A, Lew R. Regulation of cardiovascular signaling by kinins and products of similar converting enzyme systems-endopeptidases 3.4. 24.15 and 24.16 in endothelial cells: potential role in vasoactive peptide metabolism. Am J Physiol Hear Circ Physiol 2003;284:H1978-84.

63. Odya CE, Marinkovic DV, Hammon KJ, Stewart TA, Erdös EG. Purification and properties of prolylcarboxypeptidase (angiotensinase C) from human kidney. J Biol Chem 1978;253:5927-31.

64. Kassem KM, Vaid S, Peng H, Sarkar S, Rhaleb N-E. T $\beta 4-A c-S D K P$ pathway: any relevance for the cardiovascular system? Physiol Behav 2019;97:589-99.
65. Li B, Yang J, Zhao F, et al. Prevalence and impact of cardiovascular metabolic diseases on COVID-19 in China. Clin Res Cardiol 2020;109:531-8.

66. Chen N, Zhou M, Dong X, et al. Epidemiological and clinical characteristics of 99 cases of 2019 novel coronavirus pneumonia in Wuhan, China: a descriptive study. Lancet 2020;395:507-13.

67. Guan W, Ni Z, Hu Y, et al. Clinical characteristics of coronavirus disease 2019 in China. N Engl J Med 2020;382:1708-20.

68. Wang D, Hu B, Hu C, et al. Clinical characteristics of 138 hospitalized patients with 2019 novel coronavirus-infected pneumonia in Wuhan, China. JAMA 2020;323:1061-9.

69. Grasselli G, Zangrillo A, Zanella A, et al. Baseline characteristics and outcomes of 1591 patients infected with SARS-CoV-2 admitted to ICUs of the Lombardy region, Italy. JAMA 2020;323:1574-81.

70. Ikram OO, Melenotte C, Brouqui P, et al. Expression of ACE2 receptor soluble ACE2 angiotensin I angiotensin II and angiotensin (1-7) is modulated in COVID-19 patients. Available at: https://medrxiv.org/ cgi/content/short/2021.02.08.21251001.

71. Naftilan AJ, Oparil S. Inhibition of renin release from rat kidney slices by the angiotensin. Am J Physiol 1978;235:F62-8.

72. Atlas SA. The renin-angiotensin aldosterone system: pathophysiologica role and pharmacologic inhibition. J Manag Care Pharm 2007;13(8 suppl B):9-20

73. Mentz RJ, Bakris GL, Waeber B, et al. The past, present and future of renin-angiotensin aldosterone system inhibition. Int $\mathrm{J}$ Cardiol 2013;167:1677-87.

74. Ferreira AJ, Santos RA, Almeida AP. Angiotensin-(1-7): cardioprotective effect in myocardial ischemia/reperfusion. Hypertension 2001;38:665-8.

75. De Mello WC. Angiotensin (1-7) re-establishes impulse conduction in cardiac muscle during ischaemia-reperfusion. The role of the sodium pump. J Renin-Angiotensin-Aldosterone Syst 2004;5:203-8.

76. Guedes de Jesus IC, Scalzo S, Alves F, et al. Alamandine acts via $\mathrm{MrgD}$ to induce AMPK/NO activation against ANG II hypertrophy in cardiomyocytes. Am J Physiol Cell Physiol 2018;314: C702-11.

77. de Souza-Neto FP, de Morais E Silva M, de Carvalho Santuchi M, et al Alamandine attenuates arterial remodelling induced by transverse aortic constriction in mice. Clin Sci (Lond) 2019;133:629-43.

78. Kochi AN, Tagliari AP, Forleo GB, Fassini GM, Tondo C. Cardiac and arrhythmic complications in patients with COVID-19. J Cardiovasc Electrophysiol 2020;31:1003-8

79. Boukhris M, Hillani A, Moroni F, et al. Cardiovascular implications of the COVID-19 pandemic: a global perspective. Can J Cardiol 2020;36:1068-80.

80. Gupta A, Madhavan MV, Sehgal K, et al. Extrapulmonary manifestations of COVID-19. Nat Med 2020;26:1017-32.

81. Bailey AL, Dmytrenko O, Greenberg L, et al. SARS-CoV-2 infects human engineered heart tissues and models COVID-19 myocarditis. JACC Basic Transl Sci 2021;6:331-45.

82. Garg S, Garg M, Prabhakar N, Malhotra P, Agarwal R. Unraveling the mystery of Covid-19 cytokine storm: from skin to organ systems. Dermatol Ther 2020;33:e13859.

83. Azoulay E, Zafrani L, Mirouse A, et al. Clinical phenotypes of critically ill COVID-19 patients. Intensive Care Med 2020;46:1651-2. 
84. Palmieri L, Vanacore N, Donfrancesco C, et al. Clinical characteristics of hospitalized individuals dying with COVID-19 by age group in Italy. J Gerontol A Biol Sci Med Sci 2020;75:1796-800.

85. Anupama BK, Chaudhuri D. A review of acute myocardial injury in coronavirus disease 2019. Cureus 2020;12:e8426.

86. Gerc V, Buksa M. Advantages of renin-angiotensin system blockade in the treatment of cardiovascular diseases. Med Arh 2010;64: 295-9.

87. Gava E, Samad-Zadeh A, Zimpelmann J, et al. Angiotensin-(1-7) activates a tyrosine phosphatase and inhibits glucose-induced signalling in proximal tubular cells. Nephrol Dial Transplant 2009;24:1766-73.

88. Labò N, Ohnuki H, Tosato G. Vasculopathy and coagulopathy associated with SARS-CoV-2 infection. Cells 2020;9:1583-613.

89. Rello J, Storti E, Belliato M, Serrano R. Clinical phenotypes of SARSCoV-2: implications for clinicians and researchers. Eur Respir J 2020;55:4-7.

90. van Dam LF, Kroft LJM, van der Wal LI, et al. Clinical and computed tomography characteristics of COVID-19 associated acute pulmonary embolism: A different phenotype of thrombotic disease? Thromb Res 2020;193:86-9

91. Robba C, Battaglini D, Ball L, et al. Distinct phenotypes require distinct respiratory management strategies in severe COVID-19. Respir Physiol Neurobiol 2020;279:103455.

92. Levi M, Thachil J, Iba T, Levy JH. Coagulation abnormalities and thrombosis in patients with COVID-19. Lancet Haematol 2020;7: e438-40.

93. Sardu C, Gambardella J, Morelli MB, et al. Hypertension, thrombosis, kidney failure, and diabetes: Is COVID-19 an endothelial disease? A comprehensive evaluation of clinical and basic evidence. J Clin Med 2020;9:1417.

94. Kucharewicz I, Chabielska E, Pawlak D, et al. The antithrombotic effect of angiotensin-(1-7) closely resembles that of losartan. J ReninAngiotensin-Aldosterone Syst 2000;1:268-72.

95. Kucharewicz I, Pawlak R, Matys T, Pawlak D, Buczko W. Antithrombotic effect of captopril and losartan is mediated by angiotensin-(1-7). Hypertension 2002;40:774-9.

96. Zhou Y, Chi J, Lv W, Wang Y. Obesity and diabetes as high-risk factors for severe coronavirus disease 2019 (COVID-19). Diabetes Metab Res Rev 2020:e3377.

97. Bansal R, Gubbi S, Muniyappa R. Metabolic syndrome and COVID 19: endocrine-immune-vascular interactions shapes clinical course. Endocrinology 2020;161:bqaa112.

98. Kim MK, Jeon JH, Kim SW, et al. The clinical characteristics and outcomes of patients with moderate-to-severe coronavirus disease 2019 infection and diabetes in Daegu, South Korea. Diabetes Metab J 2020;44:602-13.

99. Ruiz-Ortega M, Lorenzo O, Suzuki Y, Rupérez M, Egido J. Proinflammatory actions of angiotensins. Curr Opin Nephrol Hypertens 2001;10:321-9.

100. Suzuki Y, Ruiz-Ortega M, Lorenzo O, et al. Inflammation and angiotensin II. Int J Biochem Cell Biol 2003;35:881-900.

101. Sukumaran V, Veeraveedu PT, Gurusamy N, et al. Cardioprotective effects of telmisartan against heart failure in rats in-duced by experimental autoimmune myocarditis through the modulation of angiotensinconverting enzyme-2/angiotensin 1-7/Mas receptor axis. Int J Biol Sci 2011;7:1077-92.
102. Grobe JL, Mecca AP, Lingis M, et al. Prevention of angiotensin IIinduced cardiac remodeling by angiotensin-(1-7). Am J Physiol Heart Circ Physiol 2007;292:736-42.

103. Guo YJ, Li WH, Wu R, Xie Q, Cui LQ. ACE2 overexpression inhibits angiotensin ii-induced monocyte chemoattractant protein-1 expression in macrophages. Arch Med Res 2008;39:149-54.

104. Ferreira AJ, Shenoy V, Yamazato Y, et al. Evidence for angiotensin-converting enzyme 2 as a therapeutic target for the prevention of pulmonary hypertension. Am J Respir Crit Care Med 2009;179:1048-54.

105. Sukumaran V, Veeraveedu PT, Gurusamy N, et al. Telmisartan acts through the modulation of ACE-2/ANG 1-7/mas receptor in rats with dilated cardiomyopathy induced by experimental autoimmune myocarditis. Life Sci 2012;90:289-300.

106. Sriramula S, Cardinale JP, Lazartigues E, Francis J. ACE2 overexpression in the paraventricular nucleus attenuates angiotensin II-induced hypertension. Cardiovasc Res 2011;92:401-8.

107. Patel VB, Mori J, McLean BA, et al. ACE2 deficiency worsens epicardial adipose tissue inflammation and cardiac dysfunction in response to diet-induced obesity. Diabetes 2016;65:85-95.

108. Schinzari F, Tesauro M, Veneziani A, et al. Favorable vascular actions of angiotensin-(1-7) in human obesity. Hypertension 2018;71:185-91.

109. Ware LB, Matthay MA. The acute respiratory distress syndrome. N Engl J Med 2000;342:1334-49.

110. Cheng H, Wang Y, Wang GQ. Organ-protective effect of angiotensinconverting enzyme 2 and its effect on the prognosis of COVID-19. J Med Virol 2020;92:726-30.

111. Drosten C, Günther S, Preiser W, et al. Identification of a novel coronavirus in patients with severe acute respiratory syndrome. N Engl J Med 2003;348:1967-76.

112. Totura AL, Bavari S. Broad-spectrum coronavirus antiviral drug discovery. Expert Opin Drug Discov 2019;14:397-412.

113. Tran TH, Nguyen TL, Nguyen TD, et al. Avian influenza A (H5N1) in 10 patients in Vietnam. N Engl J Med 2004;350:1179-88.

114. Spagnolo P, Balestro E, Aliberti S, et al. Pulmonary fibrosis secondary to COVID-19: a call to arms? Lancet Respir Med 2020;8:750-2.

115. George PM, Wells AU, Jenkins RG. Pulmonary fibrosis and COVID19: the potential role for antifibrotic therapy. Lancet Respir Med 2020;8:807-15.

116. Meng $\mathrm{Y}, \mathrm{Yu} \mathrm{CH}, \mathrm{Li}$ W, et al. Angiotensin-converting enzyme 2/ angiotensin-(1-7)/mas axis protects against lung fibrosis by inhibiting the MAPK/NF- $\kappa$ B pathway. Am J Respir Cell Mol Biol 2014;50:723-36.

117. Sarzani R, Giulietti F, Di Pentima C, Giordano P, Spannella F. Disequilibrium between the classic renin-angiotensin system and its opposing arm in SARS-CoV-2 related lung injury. Am J Physiol Lung Cell Mol Physiol 2020;319:L325-36.

118. Nejat R, Sadr AS. Are losartan and imatinib effective against SARS$\mathrm{CoV} 2$ pathogenesis? A pathophysiologic-based in silico study. Silico Pharmacol 2021;9:1-22.

119. Soheili M, Haji-Allahverdipoor K, Khadem-Erfan MB, et al. Combination of $\mathrm{C} 21$ and ARBs with rhACE2 as a therapeutic protocol: a new promising approach for treating ARDS in patients with coronavirus infection. Med J Islam Repub Iran 2020;34:120.

120. Shao M, Wen Z-B, Yang HH, et al. Exogenous angiotensin (1-7) directly inhibits epithelial-mesenchymal transformation induced by 
transforming growth factor- $\beta 1$ in alveolar epithelial cells. Biomed Pharmacother 2019;117:109193.

121. Meng Y, Pan M, Zheng B, et al. Autophagy attenuates angiotensin IIInduced pulmonary fibrosis by inhibiting redox imbalance-mediated NOD-like receptor family pyrin domain containing 3 inflammasome activation. Antioxid Redox Signal 2019;30:520-41.

122. Meng Y, Li T, Zhou GS, et al. The angiotensin-converting enzyme $2 /$ angiotensin (1-7)/mas axis protects against lung fibroblast migration and lung fibrosis by inhibiting the NOX4-derived ROS-mediated RhoA/Rho kinase pathway. Antioxid Redox Signal 2015;22:241-58.

123. Li X, Molina-Molina M, Abdul-Hafez A, et al. Angiotensin converting enzyme- 2 is protective but downregulated in human and experimental lung fibrosis. Am J Physiol Lung Cell Mol Physiol 2008;295:L178-85.

124. Schett G, Manger B, Simon D, Caporali R. COVID-19 revisiting inflammatory pathways of arthritis. Nat Rev Rheumatol 2020;16: $465-70$.

125. Contini C, Gallenga CE, Neri G, Maritati M, Conti P. A new pharmacological approach based on remdesivir aerosolized administration on SARS-CoV-2 pulmonary inflammation: A possible and rational therapeutic application. Med Hypotheses 2020;144:109876.

126. Bindoli S, Felicetti M, Sfriso P, Doria A. The amount of cytokinerelease defines different shades of Sars-Cov2 infection. Exp Biol Med 2020:1-7.

127. Kong J, Zhu X, Shi Y, et al. VDR attenuates acute lung injury by blocking Ang-2-Tie-2 pathway and renin-angiotensin system. Mol Endocrinol 2013;27:2116-25.

128. Castillo ME, Costa LME, Barrios JMV, et al. Effect of calcifediol treatment and best available therapy versus best available therapy on intensive care unit admission and mortality among patients hospitalized for COVID-19: a pilot randomized clinical study. J Steroid Biochem Mol Biol 2020;203:105751

129. Burrell LM, Risvanis J, Kubota E, et al. Myocardial infarction increases ACE2 expression in rat and humans. Eur Heart J 2005;26:369-75.

130. Dalan R, Bornstein SR, El-Armouche A, et al. The ACE-2 in COVID19: foe or friend? Horm Metab Res 2020;52:257-63.

131. Deshotels MR, Xia H, Sriramula S, et al. Angiotensin-II mediates ACE2 internalization and degradation through an angiotensin-II type I receptor-dependent mechanism. Hypertension 2014;64:1368-75.

132. Zhao X, Jiang Y, Zhao Y, et al. Analysis of the susceptibility to COVID-19 in pregnancy and recommendations on potential drug screening. Eur J Clin Microbiol Infect Dis 2020;39:1209-20.

133. Mancusi C, Grassi G, Borghi C, et al. Determinants of healing among patients with coronavirus disease 2019: the results of the SARS-RAS study of the Italian Society of Hypertension. J Hypertens 2021;39:376-80.

134. Iaccarino G, Grassi G, Borghi C, et al. Age and multimorbidity predict death among COVID-19 Patients: Results of the SARS-RAS study of the Italian Society of Hypertension. Hypertension 2020;76:366-72.

135. Semenzato L, Botton J, Drouin J, et al. Antihypertensive drugs and COVID-19 risk. Hypertension 2021;77:833-42.

136. Russo V, Piccinocchi G, Mandaliti V, et al. Cardiovascular comorbidities and pharmacological treatments of Covid-19 patients not requiring hospitalization. Int J Environ Res Public Health 2021;18:1-9.

137. Genet B, Vidal J-S, Cohen A, et al. COVID-19 in-hospital mortality and use of renin-angiotensin system blockers in geriatrics patients. J Am Med Dir Assoc 2020;21:1539-45.
138. Zhong Y, Zhao L, Wu G, et al. Impact of renin-angiotensin system inhibitors use on mortality in severe COVID-19 patients with hypertension: a retrospective observational study. J Int Med Res 2020;48:300060520979151

139. Palazzuoli A, Mancone M, De Ferrari GM, et al. Antecedent administration of angiotensin-converting enzyme inhibitors or angiotensin it receptor antagonists and survival after hospitalization for COVID-19 syndrome. J Am Heart Assoc 2020;9:e017364.

140. de Castelnuovo A, Bonaccio M, Costanzo S, et al. RAAS inhibitors are not associated with mortality in COVID-19 patients: findings from an observational multicenter study in Italy and a meta-analysis of 19 studies. Vascul Pharmacol 2020;135:106805.

141. Negreira-Caamaño M, Piqueras-Flores J, Martínez-DelRio J, et al. Impact of treatment with renin-angiotensin system inhibitors on clinical outcomes in hypertensive patients hospitalized with COVID-19. High Blood Press Cardiovasc Prev 2020;27:561-8.

142. Reynolds HR, Adhikari S, Pulgarin C, et al. Renin-angiotensin -aldosterone system inhibitors and risk of Covid-19. N Engl J Med 2020:1-8.

143. Bauer AZ, Gore R, Sama SR, et al. Hypertension, medications, and risk of severe COVID-19: a Massachusetts community-based observational study. J Clin Hypertens 2021;23:21-7.

144. Meng J, Xiao G, Zhang J, et al. Renin-angiotensin system inhibitors improve the clinical outcomes of COVID-19 patients with hypertension. Emerg Microbes Infect 2020;9:757-60.

145. Soleimani A, Kazemian S, Saleh SK, et al. Effects of angiotensin receptor blockers (ARBs) on in-hospital outcomes of patients with hypertension and confirmed or clinically suspected COVID-19. Am J Hypertens 2020;33:1102-11.

146. Matsuzawa $\mathrm{Y}$, Ogawa $\mathrm{H}$, Kimura $\mathrm{K}$, et al. Renin-angiotensin system inhibitors and the severity of coronavirus disease 2019 in Kanagawa, Japan: a retrospective cohort study. Hypertens Res $2020 ; 43: 1257-66$

147. Gao C, Cai Y, Zhang K, et al. Association of hypertension and antihypertensive treatment with COVID-19 mortality: a retrospective observational study. Eur Heart J 2020;41:2058-66.

148. Vila-Corcoles A, Satue-Gracia E, Ochoa-Gondar O, et al. Use of distinct anti-hypertensive drugs and risk for COVID-19 among hypertensive people: a population-based cohort study in Southern Catalonia, Spain. J Clin Hypertens (Greenwich). 2020;22:137988.

149. Desai A, Voza G, Paiardi S, et al. The role of anti-hypertensive treatment, comorbidities and early introduction of LMWH in the setting of COVID-19: a retrospective, observational study in Northern Italy. Int J Cardiol 2021;324:249-54

150. Zhang P, Zhu L, Cai J, et al. Association of inpatient use of angiotensin-converting enzyme inhibitors and angiotensin ii receptor blockers with mortality among patients with hypertension hospitalized with COVID-19. Circ Res 2020;126:1671-81.

151. Mancia G, Rea F, Ludergnani M, Apolone G, Corrao G. Renin-angiotensin-aldosterone system blockers and the risk of Covid-19. N Engl J Med 2020;382:2431-40

152. Li J, Wang X, Chen J, Zhang H, Deng A. Association of reninangiotensin system inhibitors with severity or risk of death in patients with hypertension hospitalized for Coronavirus disease 2019 (COVID-19) infection in Wuhan, China. JAMA Cardiol 2020;5:825-30 
153. Lopes RD, Macedo AVS, de Barros E, Silva PGM, et al. Effect of discontinuing vs continuing angiotensin-converting enzyme inhibitors and angiotensin ii receptor blockers on days alive and out of the hospital in patients admitted with COVID-19: a randomized clinical trial. JAMA 2021;325:254-64.
154. Cohen JB, Hanff TC, William P, et al. Continuation versus discontinuation of renin-angiotensin system inhibitors in patients admitted to hospital with COVID-19: a prospective, randomised, open-label trial. Lancet Respir Med 2021;9:275-84. 